Gut, 1976, 17, 735-739

\title{
Transient paraproteinaemia in a patient with coeliac disease
}

\author{
A. S. PEÑA, JANNY v. NIEUWKOOP, H. R. E. SCHUIT, W. TH. J. M. HEKKENS, \\ AND A. J. CH. HAEX \\ From the Departments of Gastroenterology and of Immunohaematology, State University Hospital, Leyden, \\ and Institute for Experimental Gerontology (TNO), Rijswijk, The Netherlands
}

SUMMARY A case is reported of a 43 year old man who suffered from a grass pollen allergy and a malabsorption syndrome and in whom a paraproteinaemia was found. The grass pollen hypersensitivity was abolished by desensitization. The malabsorption syndrome was found to be due to coeliac disease-that is, a 'flat' mucosa of the jejunum with an almost normal ileal mucosafollowed by clinical recovery and morphological improvement on a gluten-free diet. A short period of gluten reintroduction caused deterioration of the jejunum. The monoclonal immunoglobulin (Ig G- $\lambda$ ) diminished and disappeared in the course of three years. Although it has not been possible to demonstrate that this paraprotein had anti-gliadin activity, it is suggested that the constant stimulation of the gut reticuloendothelial system by gluten might bear some relation to the appearance of the paraproteinaemia.

Dameshek and Schwartz (1959) suggested that chronic stimulation of the reticuloendothelial system might influence the appearance of plasma cell dyscrasia. Aleutian disease of mink, which is characterised by a diffuse proliferation of plasma cells, terminates in some mink as a paraproteinaemia, together with the appearance of Bence Jones proteinuria (Porter et al., 1965). In man, it has been stressed that chronic inflammatory processes can be associated with paraproteinaemia (Combined Staff Clinic, 1968), thus giving support to the suggestion of Dameshek and Schwartz (1959).

In adult coeliac disease there is evidence of lymphoreticular dysfunction (McCarthy et al., 1966; Hobbs and Hepner, 1968; Blecher et al., 1969) and there are data supporting an increased incidence of lymphoma and reticulosis (Gough et al., 1962; Harris et al., 1967).

Transient paraproteins have been found in association with a variety of conditions (Young, 1969). Although their significance is not entirely clear, in some case they may represent an antibody response (Seligmann et al., 1971).

We wish to report the case of a transient monoclonal IgG of the lambda type in a patient with adult coeliac disease.

Received for publication 24 March 1976

\section{Case history}

B.M.B., a male, was born in Indonesia (on 30 October 1926). His father was Dutch and his mother Indonesian. The patient emigrated to The Netherlands when he was 20 years of age. Before this he had suffered from malaria, dysentery, and pleuritis. He remained well till 1965 when he had several episodes of hay fever and allergic rhinitis. In May 1969 he visited the Allergy Clinic at our hospital and it was found that he was highly sensitive to grass pollen and to a minor extent to cat and dog hair. There was also a delayed skin reaction to Haemophilus influenzae and streptococcus. He was advised to follow a cure of desensitization with grass pollen and was vaccinated against $H$. influenzae.

He followed this treatment from 1969 to 1971 by which time all his allergic symptoms disappeared. In 1969 he was seen for the first time at our department of gastroenterology. He had a 24 year history of vague abdominal symptoms but in the last few months he had diarrhoea almost every day with colicky abdominal pain.

Laboratory investigations in 1969 showed an ESR of $20 \mathrm{~mm}$ in the first hour, a mild macrocytic anaemia: $\mathrm{Hb} 11.7 \mathrm{~g} / \mathrm{dl}$; erythrocytes $2.9 \times 10^{6}$ per $\mathrm{mm}^{3}$, leucopenia 900 to 1400 with neutropenia, low folic acid $0.6 \mathrm{mg} / \mathrm{ml}$. Vitamin $B_{12}$ in blood was 
normal. Schilling test was normal as well (29.3\%).

SERUM IMMUNOGLOBULINS

IgA and IgM were measured by radial immunodiffusion using the Tri-Partigen plates (Behring).

\begin{tabular}{|c|c|c|c|c|c|c|}
\hline & \multicolumn{5}{|l|}{ Date } & \multirow{2}{*}{$\begin{array}{l}\text { Normal range } \\
(\mathrm{mg} / 100 \mathrm{ml})\end{array}$} \\
\hline & 19.1 .70 & 6.10 .72 & 13.12 .72 & 10.2 .75 & 1.5 .75 & \\
\hline $\begin{array}{l}\text { IgA } \\
\text { IgM }\end{array}$ & $\begin{array}{r}175 \\
38\end{array}$ & $\begin{array}{l}150 \\
280\end{array}$ & $\begin{array}{r}226 \\
68\end{array}$ & $\begin{array}{r}269 \\
88\end{array}$ & $\begin{array}{l}268 \\
100\end{array}$ & $\begin{array}{l}90-450 \\
60-250\end{array}$ \\
\hline
\end{tabular}

IMMUNOLOGICAL STUDIES

Agar electrophoresis showed a definite homogeneous band in the gamma region (Fig. 1). Immunoelectrophoresis and immunoselection (Rádl, 1972) showed an IgG paraprotein of the lambda type.

Immunofluorescence of the bone marrow (1969) revealed an increased number of plasma cells which were mainly positive for IgG. Seven per cent of the positive cells were $\operatorname{IgA}, 5 \% \operatorname{IgM}, 2 \% \operatorname{IgD}$, and $86 \% \mathrm{IgG} ; 90 \%$ of the IgG positive cells were of the lambda type.

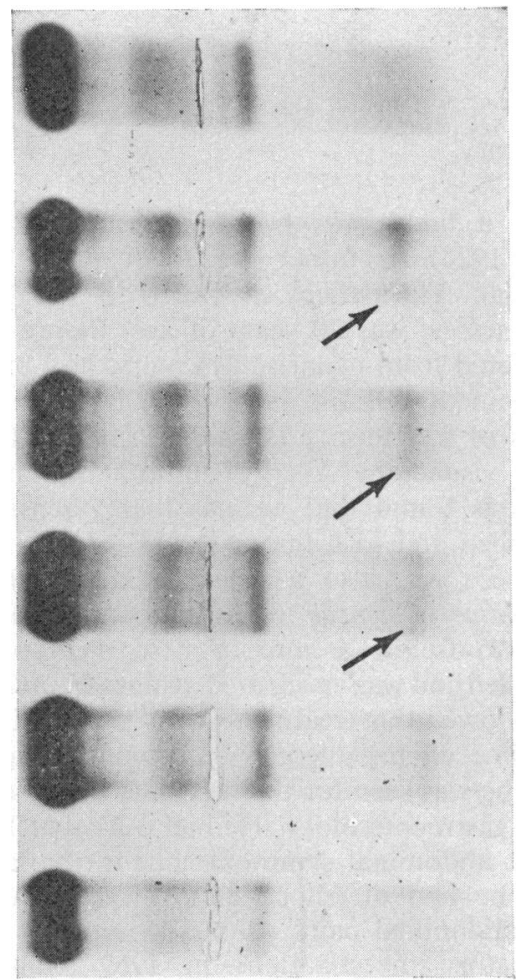

Fig. 1 Agarose gel electrophoresis of serum. 1 and 6 normal human serum, 2, 3, 4, and 5 serum from the patient in 1970, 1971, 1972, and 1973 respectively. Arrows indicate $M$ component.
Immunofluorescence investigation of jejunal biopsy specimen (1969) showed numerous IgA positive cells, many IgM, and several IgG. There was no indication of preponderance of IgG-positive cells.

Immunofluorescence of the bone marrow (1975) showed IgA pos. $41 \cdot 6 \%$, IgM pos. $8.0 \%$, IgG pos. $54.4 \%$, IgD pos. $1.0 \%$, IgE pos. $0 \%$. Ratio $\mathrm{K} / \lambda$ light chains $=63 \cdot 1 / 36 \cdot 9$ (normal).

\section{IMMUNOABSORPTION}

In order to study possible antigliadin activity of this paraprotein, immunoabsorption was tried in a column of sepharose to which gliadin was coupled. To prove the proper functioning of this column, serum of rabbit immunised with gliadin was applied first.

As can be seen in Fig. 3 one of the precipitation bands is retained by the column. This has been

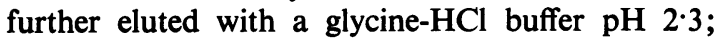
the eluate showed a precipitation line against gliadin (well 4 of Fig. 3). The same experiment was repeated with the patient's serum. Neither this immunodiffusion nor the immunoelectrophoresis of the same fractions of the patient's serum against rabbit-anti-human immunoglobulins (Fig. 2) gave evidence of any anti-gliadin component.

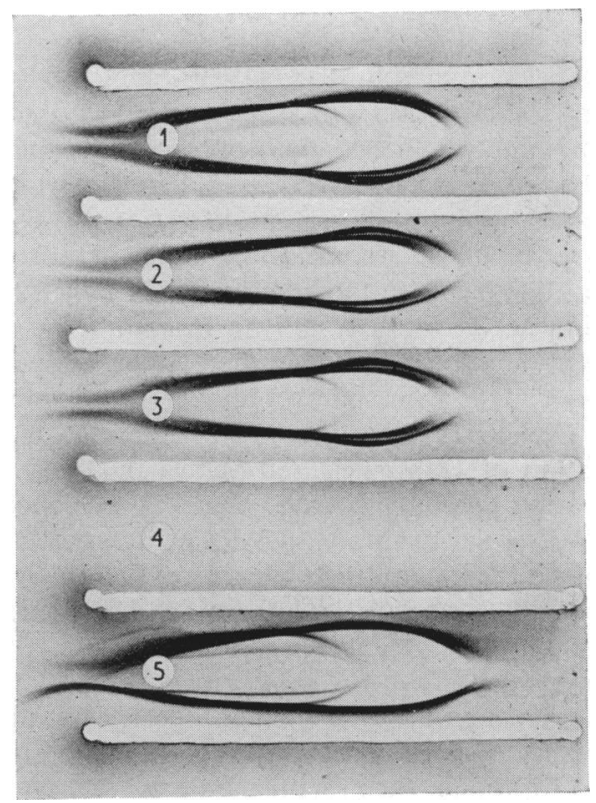

Fig. 2 Immunoelectrophoresis of serum against rabbit antihuman immunoglobulins. 1. Serum of the patient. 2. Serum of the patient after passing a Sepharose B4 column. 3. Serum of the patient after passing a Sepharose B4 column coupled to gliadin. 4. Eluate of the second column with glycine-HCl buffer, $\mathrm{pH} \mathrm{2 \cdot 3.} \mathrm{5.} \mathrm{Normal}$ human serum. 


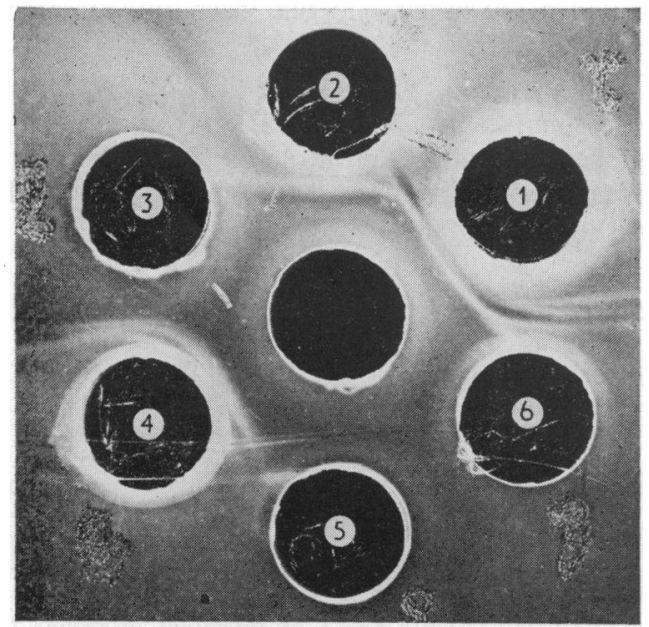

Fig. 3 Ouchterlony plate. In the central well of gliadin (5 $\mathrm{mg} / \mathrm{ml})$ 1. Rabbit serum (15-3-74) 2. Rabbit serum passed through column of sepharose B4 coupled to gliadin. 3. Gliadin $(0.5 \mathrm{mg} / \mathrm{ml})$. 4. Eluate obtained with glycine- $\mathrm{HCl}$ buffer, $\mathrm{pH} 2 \cdot 3$ after passage of rabbit's serum. 5. Free well. 6. Gliadin $(0.5 \mathrm{mg} / \mathrm{ml})$.

STUDIES OF SMALL INTESTINE

The glucose tolerance test was normal (maximum rise $25 \mathrm{mg} \%$ ), a lactose tolerance test was flat (maximum rise 4-5 mg), and a xylose test was also abnormal $(13.8 \%$ were excreted in five hours' urine after $5 \mathrm{~g}$ d-xylose; a normal level being more than $27 \%$ ). A jejunal biopsy specimen showed a hyperplastic type of mucosal atrophy with an increased number of interepithelial lymphocytes and an increased number of plasma cells in the lamina propria. The ileum biopsy specimen showed a mild partial villous atrophy. A fat balance showed a mild steatorrhoea $(6 \cdot 8 \mathrm{~g} / 24 \mathrm{~h})$.

\section{TREATMENT AND COURSE}

The patient was treated with folic acid, iron tablets, and a gluten-free diet with a good clinical response and normalization of biochemical parameters. Repeated small intestinal biopsies showed improvement of the villous architecture with diminution of the mononuclear cell infiltrate. Three years later he was challenged with $3.5 \mathrm{~g}$ gliadin and there was an immediate deterioration of the small intestinal mucosa.

The effect of gliadin on the intestinal mucosa was assessed in two ways: (1) enzymatically, by estimating disaccharidase activity, and (2) by quantitative histological examination, using the method of Dunnill and Whitehead (1972). Biopsy specimens were taken under fluoroscopic control
$20 \mathrm{~cm}$ beyond the duodenojejunal flexure using a hydraulic multiple biopsy instrument. Biopsy specimens were taken before and three and 24 hours after instilling $3.5 \mathrm{~g}$ gliadin dissolved in water (pH 6.8) via a tube which was located fluoroscopically $10 \mathrm{~cm}$ above the site of biopsy.

\section{DISACCHARIDASE ESTIMATIONS}

These were performed using the method of Dahlqvist (1970). Results are expressed in units per $g$ protein.

\begin{tabular}{lccr}
\hline & Before challenge & \multicolumn{2}{c}{ After challenge $(h)$} \\
\cline { 3 - 4 } & & 3 & 24 \\
\hline Lactase & 3 & 2 & 2 \\
Sucrase & 17 & 9 & 9 \\
Maltase & 81 & 44 & 39 \\
\hline
\end{tabular}

QUANTITATIVE HISTOLOGICAL EXAMINATION The method of Dunnill and Whitehead (1972) was followed. A template of 15 lines of equal length was drawn according to the specifications of Weibel (1963) on an eye-piece graticule prepared for us by Graticules Ltd. The objective and ocular combination of the microscope yielded a magnification of $\times 100$. At this magnification the length of each line east on the section was $1.8 \times 10^{-2} \mathrm{~cm}$.

The index c:lh, which is related to the surface-tovolume ratio, was calculated. The mean number of hits per microscopic field $(\bar{h})$ was also determined. It is proportional to the mucosal volume.

\begin{tabular}{llll}
\hline & Before challenge & \multicolumn{2}{l}{ After challenge $(h)$} \\
\cline { 3 - 4 } & & 3 & 24 \\
\hline C:Ih & 15.2 & 14.3 & 10.9 \\
$\bar{h}$ & $20.9 \pm 3.5$ & $13.2 \pm 1.98$ & $13.7 \pm 1.85(\mu \pm$ SD \\
\hline
\end{tabular}

Both the disaccharidases assay and the morphological study showed a response to the gliadin instillation thus confirming the patient's sensitivity to gluten.

\section{Discussion}

Transient paraproteins-that is, homogeneous immunoglobulins which suddenly appear in the serum and disappear within weeks or months-are not very common. Young reviewed the literature in 1969 and, with his five cases, the total amounted to 36 cases.

On the other hand, there is clinical and experimental evidence (for review, see Rádl, 1975) that paraproteins appear often in immunodeficiency diseases. In a longitudinal study of three patients 
with the Wiskott-Aldrich syndrome made by Rádl et al., it was found that they all produced temporarily one or more populations of paraproteins. Studies made in experimental models (Rádl, 1975) showed that the absence or delay in maturation of the T-cells could contribute to a high frequency of transient paraproteins.

Weetman et al. (1974) have studied the distribution and faecal loss of peripherally harvested lymphocytes labelled with 51-Cr and reinjected into human subjects and have shown that the five-day faecal loss of untreated patients with coeliac disease was as great as that of patients with lymphangiectasia.

Ferguson (1974) has suggested that thymusdependent lymphocytes may be involved in the pathogenesis of the jejunal lesion and recently O'Donoghue et al. (1975) have measured circulating T-cells in the blood of coeliac patients and controls. They have shown that the relative and absolute number of T-cells were decreased in untreated coeliac patients compared with controls.

It might be, then, that there is a link between coeliac disease and the production of this transient paraproteinaemia in our patient. In favour of a immunodeficiency state were his leucopenia and low IgM. Both recovered to normal levels when a gluten-free diet was instituted.

It might be that the paraproteinaemia represents another example of altered immunity in coeliac disease. Although we have not been able to find another report of a transient paraprotein in coeliac disease, Cooke (1969) has reported three cases of steatorrhoea associated with an IgG paraproteinaemia. Presumably they were cases of coeliac disease. No further details are given in the text. Other examples of disordered immunity in coeliac disease are dysgammaglobulinaemia (Hobbs et al., 1969) and the occurrence of mixed cryoglobulinaemia in four patients with coeliac disease (Doe et al., 1972).

Two cases of transient paraproteinaemia have been reported in association with low-folic acid (Roman and Coles, 1966). They disappeared as soon as folic acid was given. Although our patient had a low folic acid at the time of diagnosis, the paraprotein disappeared three years later when this deficiency and his anaemia had been corrected for a long period of time.

It has been suggested that transient paraproteins are antibodies (Seligman et al., 1971; Rádl, 1975). The paraprotein in our patient had no detectable anti-gliadin activity. Whether it represented an antibody against one of the multiple vaccines he received is a possibility, although unlikely. Penny and Hughes (1970) were not able to find any para- protein in $\mathbf{3 0}$ cases who had been fully treated by desensitization.

We would like to thank Dr J. Rádl from the Institute for Experimental Gerontology, Rijswijk, for his advice and criticism and Mrs P. H. Lems-van Kan for the immunoabsorption study.

\section{References}

Blecher, T. E., Brzechwa-Ajdukiewicz, A., McCarthy, C. F., and Read, A. E. (1969). Serum immunoglobulins and lymphocyte transformation studies in coeliac disease. Gut, 10, 57-62.

Combined Staff Clinic (1968). Plasma cell dyscrasias, current clinical and biochemical concepts. American Journal of Medicine, 44, 256-269.

Cooke, K. B. (1969). Essential paraproteinaemia. Proceedings of the Royal Society of Medicine, 62, 777-778.

Dahlqvist, A. (1970). Assay of intestinal disaccharidases. Enzymologia Biologica et Clinica, 11, 52-66.

Dameshek, W., and Schwartz, R. S. (1959). Leukemia and auto-immunization-some possible relationships. Blood, 14, 1151-1158.

Doe, W. F., Evans, D., Hobbs, J. R., and Booth, C. C. (1972). Coeliac disease, vasculitis, and cryoglobulinaemia. Gut, 13, 112-123.

Dunnill, M. S., and Whitehead, R. (1972). A method for the quantitation of small intestinal biopsy specimen. Journal of Clinical Pathology, 25, 243-246.

Ferguson, A. (1974). Lymphocytes. In Coeliac Disease, pp. 265-276. Edited by W. T. J. M. Hekkens and A. S. Pena. Medical and Technical Pub. Co.: Lancaster.

Gough, K. R., Read, A. E., and Naish, J. M. (1962). Intestinal reticulosis as a complication of idiopathic steatorrhoea. Gut, 3, 232-239.

Harris, O. D., Cooke, W. T., Thompson, H., and Waterhouse, J. A. H. (1967). Malignancy in adult coeliac disease and idiopathic steatorrhoea. American Journal of Medicine, 42, 899-912.

Hobbs, J. R., and Hepner, G. W. (1968). Deficiency of gamma M-globulins in coeliac disease. Lancet, 1, 217-220.

Hobbs, J. R., Hepner, G. W., Douglas, A. P., Crabbé, P. A., and Johansson, S. G. O. (1969). Immunological mystery of coeliac disease. Lancet, 2, 649-650.

McCarthy, C. F., Fraser, I. D., Evans, K. T., and Read, A. E. (1966). Lymphoreticular dysfunction in idiopathic steatorrhoea. Gut, 7, 140-148.

Metzger, H. (1969). Myeloma proteins and antibodies. American Journal of Medicine, 47, 837-844.

O'Donoghue, D. P., Lancaster-Smith, M., and Kumar, P. J. (1975). Depletion of thymus-dependent lymphocytes in adult coeliac disease. Gut, 16, 392-393.

Penny, R., and Hughes, S. (1970). Repeated stimulation of the reticulo-endothelial system and the development of plasma-cell dyscrasias. Lancet, 1, 77-78.

Porter, D. D., Dixon, F. J., and Larsen, A. E. (1965). The development of a myeloma-like condition in mink with Aleutian disease. Blood, 25, 736-742.

Rádl, J. (1972). Immunoselection technique and its applications. In Protides of the Biological Fluids, vol. 19, pp. 541-545. Edited by H. Peeters. Pergamon Press: Oxford.

Rádl, J. (1975). Immune system disorders in man and in experimental models accompanied by the production of homogeneous immunoglobulins-paraproteins. In Protides of the Biological Fluids, vol. 23, pp. 405-408. Edited by H. Peeters.Pergamon Press,: Oxford. 
Rádl, J., Dooren, L. J., Vossen, J. M. J. J., Morell, A., Skvaril, F., and Uittenbogaart, C. H. (In preparation.)

Roman, W., and Coles, M. (1966). Paraproteins in folic-acid deficiency. Lancet, 1, 211-212.

Seligmann, M., Danon, F., and Clauvel, J. P. (1971). Natural history of monoclonal immunoglobulins. British Medical Journal, 2, 321-322.
Weetman, A. P., Haggith, J., and Douglas, A. P. (1974) Enteric loss of lymphocytes in coeliac disease and in Crohn's disease. Gut, 15, 823.

Weibel, E. R. (1963). Principles and methods for the morphometric study of the lung and other organs. Laboratory Investigation, 12, 131-155.

Young, V. H. (1969). Transient paraproteins. Proceedings of the Royal Society of Medicine, 62, 778-780. 